\title{
Cerebrovascular accident and myocardial infarction associated with anticardiolipin antibodies in a young woman with systemic lupus erythematosus
}

\author{
YORAM MAARAVI, ${ }^{1}$ EYAL RAZ, ${ }^{1}$ DAN GILON ${ }^{1}$ AND ALAN RUBINOW \\ From the ${ }^{1}$ Department of Medicine, Mount Scopus, and the ${ }^{2}$ Rheumatology Unit, Department of Medicine A, \\ Hadassah University Hospital, Jerusalem, Israel
}

SUMMARY A 26 year old woman with systemic lupus erythematosus, including malar rash, photosensitivity, and arthritis, developed a cerebrovascular accident and acute myocardial infarction. High titres to antinuclear factor, anti-DNA antibodies, positive Venereal Disease Research Laboratory (VDRL) test, and anticardiolipin antibodies were found in her serum. A possible association between the presence of anticardiolipin antibodies and the two major thrombotic events is discussed.

Recent studies suggest that anticardiolipin antibodies may be responsible for a variety of laboratory and clinical phenomena in up to $61 \%$ of patients with systemic lupus erythematosus (SLE). These include lupus anticoagulant, biological false positive test for syphilis, thrombocytopenia, recurrent abortions, intrauterine fetal death, and thromboembolism. ${ }^{1-5}$

We describe here a young woman with SLE, not receiving corticosteroid treatment, who developed a cerebrovascular accident and acute myocardial infarction in the presence of a high titre of anticardiolipin antibodies.

\section{Case report}

A 26 year old woman was admitted in February 1986 because of crushing anterior chest pain of a few hours' duration. From the age of 12 she was known to have had a butterfly malar rash, photosensitivity, and recurrent bouts of arthritis. Five years before admission she developed a left hemispheric cerebrovascular accident due to thrombotic obstruction of the left internal carotid artery, which was confirmed by carotid arteriography. She denied risk factors for ischaemic heart disease, taking oral contraceptives, or receiving corticosteroid treatment. On admission she appeared acutely ill and her vital signs were

Accepted for publication 20 February 1989.

Correspondence to Dr Yoram Maaravi, Department of Medicine, Hadassah University Hospital, Mount Scopus, PO Box 24035, Jerusalem 91240, Israel. normal. The erythrocyte sedimentation rate was 97 $\mathrm{mm} / \mathrm{h}$. Haemogram and coagulation tests were normal. Urinary sediment, serum electrolytes, albumin, liver and kidney function tests, serum cholesterol, triglycerides, and high density lipoprotein cholesterol were normal. Creatine kinase was initially $182 \mathrm{U} / \mathrm{l}$ (normal $<100 \mathrm{U} / \mathrm{l}$ ) and reached a peak of $376 \mathrm{U} / \mathrm{l}$ on the second day, while aspartate aminotransferase was initially $30 \mathrm{U} / \mathrm{l}$ (normal $<40 \mathrm{U} / \mathrm{l})$ and increased to $60 \mathrm{U} / \mathrm{l}$. The electrocardiogram on admission showed a non- $Q$ wave infarction of the inferior wall. Echocardiography disclosed neither valvular abnormalities nor vegetations. Antinuclear antibody titre was 3 on a 1-4 scale. Venereal Disease Research Laboratory (VDRL) titre was 1/16. Anticardiolipin antibody concentration (measured by radioimmunoassay using ${ }^{125} \mathrm{I}$ protein $\mathrm{A}$ as a detecting developer) was $6090 \mathrm{cpm}$ (normal <2000). Anti-DNA antibodies were $22 \mu \mathrm{g} / \mathrm{ml}$ (normal $<1 \cdot 5$ ). Serum C3 was $530 \mathrm{mg} / \mathrm{l}$ and $\mathrm{C} 4$ was $340 \mathrm{mg} / \mathrm{l}$ (normal $600-1100$ and $250-500$ respectively). A skin biopsy showed no evidence of vasculitis.

On admission to the intensive care unit she responded remarkably to sublingual nitrates and calcium channel blockers. Treatment with nitrates and aspirin was started during the following hours. The laboratory investigation indicated that she had SLE, and treatment with prednisone $(60 \mathrm{mg} /$ day $)$ was started. In the remainder of her hospital course we noticed severe emotional lability, which was attributed to her basic disease and to the steroid 
treatment. During the ensuing 30 months her corticosteroid treatment was tapered slowly and, presently (January 1989), she is receiving $10 \mathrm{mg}$ prednisone daily and aspirin, and functions normally.

\section{Discussion}

The patient described here meets five of the revised criteria for $\mathrm{SLE}^{6}$ : malar rash, photosensitivity, arthritis, positive antinuclear antibody test, and an immunological disorder (positive VDRL). Her clinical course is remarkable in that despite relatively mild disease that did not require intensive treatment she developed two life threatening thrombotic events in the brain and heart.

Cardiac involvement in SLE is well recognised and most frequently manifests as pericarditis, myocarditis, and endocarditis. ${ }^{78}$ Myocardial infarction during the course of SLE is rare and only a few cases have been reported. ${ }^{-18}$ The pathogenesis of myocardial infarction in SLE is usually related to coronary atherosclerosis, possibly accelerated by corticosteroid administration. ${ }^{11}$ Furthermore, coronary arteritis is a rare process, which may culminate in myocardial infarction in patients with SLE. ${ }^{10}$ Our patient's youth, the lack of risk factors for coronary heart disease, and the previous thrombotic event in the presence of anticardiolipin antibodies support the contention that the myocardial infarction was due to coronary artery thrombosis.

Anticardiolipin antibodies are detected in a spectrum of autoimmune disorders, and high serum concentrations have been measured in up to $61 \%$ of patients with SLE. ${ }^{1}$ Harris et al provided data suggesting that lupus anticoagulant and anticardiolipin antibodies are identical and show closely related specificity. Their presence is associated with recurrent fetal loss, thrombocytopenia, and recurrent thromboembolic events, which is attributed to their inhibition of the prothrombinase complex. ${ }^{45}$ Among the thromboembolic events, cerebral infarction was frequent. ${ }^{1920}$ Eight out of nine patients with cerebral infarction had high concentrations of anticardiolipin antibodies. ${ }^{1} 1920$ In addition, Petri et al found that $50 \%$ of patients with SLE and cerebral infarction had raised anticardiolipin antibody concentrations. ${ }^{21}$

Furthermore, anticardiolipin antibodies may be a useful marker in monitoring disease activity in patients with SLE. ${ }^{22}{ }^{23}$ It is noteworthy that recurrent fetal loss in women with anticardiolipin antibodies/lupus anticoagulant can be reduced significantly by the use of steroids and aspirin. ${ }^{24}$

The association between acute myocardial infarc- tion and anticardiolipin antibodies in patients with SLE is rare. Recently, Asherson et al ${ }^{18}$ and others ${ }^{25}$. described myocardial infarction associated with anticardiolipin antibodies in young patients suffer- $\overrightarrow{\bar{F}}$ ing from SLE, 'lupus-like' disease, and the 'primary'? antiphospholipid syndrome. These data suggest that anticardiolipin antibodies may have had a patho- $\frac{\bar{c}}{\bar{c}}$ genetic role in the ischaemic events in our patient as well as in others.

We gratefully acknowledge the help of Mrs Shirley Roth in the $\vec{\circ}$ preparation of this manuscript.

\section{References}

1 Harris E N, Gharavi A E, Boey M L, et al. Anticardiolipin antibodies detection by radioimmunoassay and association with thrombosis in SLE. Lancet 1983; ii: 1211-4.

2 Harris E N, Loizou S, Englert $\mathrm{H}$, et al. Anticardiolipipo antibodies and lupus anticoagulant. Lancet 1984; iii: 1099.

3 Harris E N, Gharavi A E, Loizou S, et al. Cross-reactivity op antiphospholipid antibodies. J Clin Lab Immunol 1985; 16: 1-6.

4 Harris E N, Asherson R A, Gharavi A E, Morgan S H, Derue G J, Hughes G R V. Thrombocytopenia in SLE and relateff autoimmune disorders: association with anticardiolipin antibodies. Br J Haematol 1985; 59: 227-30.

5 Derue G J, Englert H J, Harris E N, et al. Fetal loss in SLE: association with anticardiolipin antibodies. J Obstet Gynegoto Neotal Nurs 1985; 5: 207-9.

6 Tan E M, Cohen A S, Fries J S, et al. The 1982 revised criteria for the classification of SLE. Arthritis Rheum 1982; 25: 12717 .

7 Libman E, Sacks B. A hitherto undescribed form of valv and mural endocarditis. Arch Intern Med 1924; 33: 701-32."

8 Dubois E L, Tuffanelli D L. Clinical manifestations of SLEŌ computer analysis of 520 cases. JAMA 1964; 190: 104-11.

9 Homcy C J, Liberthson R R, Fallon J T, Gross S, Miller L M Ischemic heart disease in SLE in the young patient: report of six cases. Am J Cardiol 1982; 49: 478-84.

10 Badui E, Garcia-Rubi D, Robles E, et al. CardiovasculaD manifestations of SLE. Prospective study of 100 patients? Angiology 1985; 36: 431-41.

11 Bulkley B H, Roberts W C. The heart in SLE and the changes induced in it by corticosteroid therapy: a study of 36 necropsen patients. Am J Med 1975; 58: 243-64.

12 Tsakraklides V G, Blieden L C, Edwards J E. Coronary atherosclerosis and myocardial infarction associated with sys? temic lupus erythematosus. Am Heart $J$ 1974; 87: 637-41.

13 Takatsu Y, Hattori R, Sakaguohi K, Yui Y, Kawai C. Acutes myocardial infarction associated with systemic lupus erythematosus documented by coronary arteriograms. Chest $1985 ; 88$ ? $147-9$.

14 Shalev Y, Green L, Pollack A, Bentwich Z. Myocardiaf infarction with central retinal artery occlusion in a patient witlf. antinuclear antibody-negative systemic lupus erythematosus $N$ Arthritis Rheum 1985; 28: 1185-7.

15 Vermylen J, Blockmans D, Spitz B, Deckmyn H. Thrombosiß̂ and immune disorders. Clin Haematol 1986; 15: 393-412.

16 Asherson R A, Harris E N, Gharavi A, Hughes G R V Myocardial infarction in systemic lupus erythematosus an 'lupus like' disease. Arthritis Rheum 1986; 29: 1292-3.

17 Asherson R A, Mackay I R, Harris E N. Myocardial infarctiof in a young man with systemic lupus erythematosus, deep vei thrombosis and antibodies to phospholipid. Br Heart J 1986; 56; $190-3$.

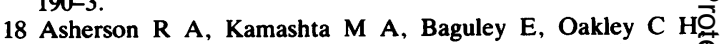
Rowell N R, Hughes $G R$ V. Myocardial infarction an 
antiphospholipid antibodies in SLE, 'lupus-like' disease and the 'primary' antiphospholipid syndrome. Br J Rheumatol 1988; 27: 54.

19 Boey M L, Colaco C B. Gharavi A E, Belkon K, Loizov S, Hughes G R V. Thrombosis in SLE: striking association with the presence of circulating 'lupus anticoagulant'. $\mathrm{Br}$ Med J 1983; 287: 1021-3.

20 Landi G, Calloni M V, Sabbadini M G. Recurrent ischemic attacks in young adults with lupus anticoagulant. Stroke 1983; 14: 377-9.

21 Petri M, Rheinschmidt M, Whiting-O'Keefe Q, Hellman D, Corash L. The frequency of lupus anticoagulant in SLE: a study of sixty consecutive patients by activated partial thromboplastin time, Russell viper venom time and anticardiolipin antibody levels. Ann Intern Med 1987; 106: 524-31.
$22 \mathrm{Raz}$ E, Michaeli J, Rosenmann E, Rubinow A, Popovtzer M M. Antinuclear antibody-negative systemic lupus erythematosus: close correlation between disease activity and appearance of circulating anticoagulant. Isr J Med Sci 1988; 24: 105-8.

23 Isenberg D A, Colaco C B, Dudeney C, Todd-Pokropek A, Snaith M L. The relationship of anti-DNA antibody idiotypes and anticardiolipin antibodies to disease activity in SLE. Medicine (Baltimore) 1986; 65: 46-55.

24 Branch D W, Scott J R, Kochenour N K, Hershgold E. Obstetric complications associated with the lupus anticoagulant. N Engl J Med 1985; 313: 1322-6.

25 Hamsten A, Norberg R, Björkholm M, De Faire V. Antibodies to cardiolipin in young survivors of myocardial infarction: an association with recurrent cardiovascular events. Lancet 1986; i: 113-6. 